\title{
ON THE LIKELY PALAEOELEVATION OF THE TURONIAN - CONIACIAN ARMAN FLORA SITE (NORTH-EASTERN ASIA)
}

\author{
ALEXEI B. HERMAN \\ Geological Institute, Russian Academy of Sciences, 7 Pyzhevsky Pereulok, 119017 Moscow, Russia; e-mail: alexeiherman@gmail.com.
}

Herman, A. B. (2018): On the likely palaeoelevation of the Turonian - Coniacian Arman Flora site (North-eastern Asia). - Fossil Imprint, 74(1-2): 159-164, Praha. ISSN 2533-4050 (print), ISSN 2533-4069 (on-line).

\begin{abstract}
The Turonian - Coniacian (Late Cretaceous) Arman Flora (North-eastern Russia, Magadan District) exhibits a high diversity of fossil angiosperms (28 dicot species). Based on their physiognomy, palaeoclimate variables were estimated showing that the flora experienced a humid warm-temperate climate without any pronounced seasonality. Palaeoclimate variables estimated for the coastal plain floras (Penzhina, Kaivayam and Tylpegyrgynai floras, North-eastern Russia) are the same (within analytical errors) as those estimated for the Arman Flora that existed within uplands of the Okhotsk-Chukotka volcanogenic belt. This conclusion implies that the elevation of the intermontane basin of the Arman Flora biotope was not high, presumably not more than $600 \mathrm{~m}$ - and not sufficient to be reflected in palaeoclimate experienced by the Arman Flora.
\end{abstract}

Key words: CLAMP, angiosperms, palaeoaltitude, Late Cretaceous, Russian Far East

Received: March 9, 2018 | Accepted: May 4, 2018 | Issued: August 31, 2018

\section{Introduction}

In the Late Cretaceous, Asia was a large land mass surrounded by marine basins (Text-fig. 1). During that time, three major geological and palaeogeographical structures existed within the north-eastern rim of Asia. The marginal continental Okhotsk-Chukotka volcanogenic belt formed a volcanic upland adjoined by the Anadyr-Koryak area of coastal alluvial plains and lowlands to the east, while VerkhoyanskChukotka area of plains, low and hilly to various degrees, laid to the west. Several Turonian - Coniacian floras are known within these structures (Herman 1999). Among them, the Arman Flora (Magadan District) is one of the richest and best studied (Herman et al. 2016). It existed in an intermountain trough within this volcanic upland. According to Vakhrameev (1991), this flora, as well as numerous other Late Cretaceous floras of North-eastern Russia and Alaska (Herman 2013; http://arcticfossils.nsii.org.cn/), belonged to the SiberianCanadian palaeofloristic region characterised by a warm temperate and humid palaeoclimate.

The Arman Flora is the oldest flora known to have existed in the volcanic uplands of the Okhotsk-Chukotka volcanogenic belt. This belt extends along the northeastern margin of the Asian continent (Text-fig. 2) from the Dzhugdzhur Range in the southwest to the Chukotka Peninsula in the northeast (Belyi 1977). This belt was formed in the middle and second half of the Cretaceous (presumably in the Turonian - Campanian time) as a

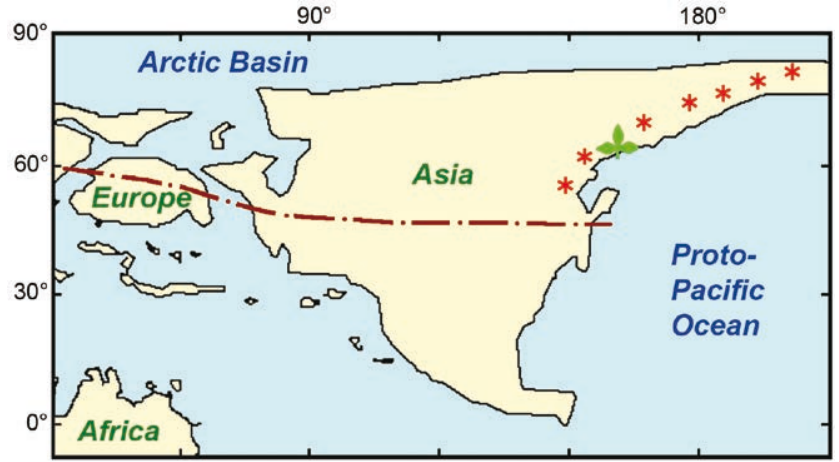

Text-fig. 1. Palaeogeographical scheme (distribution of land and sea basins) in part of Eurasia at the beginning of the Late Cretaceous (modified from Spicer et al. 2008). The green leaf symbol indicates the site of the Arman Flora. Asterisks indicate the Okhotsk-Chukotka volcanogenic belt. Dashdotted line indicates the boundary between the SiberianCanadian and Euro-Sinian palaeofloristic regions (modified from Vakhrameev 1991).

result of intense volcanism. Judging from the composition and geologic structures of the volcanic rocks, the possible height of individual volcanoes was estimated to have been 2,000-3,000 m, or possibly even more, by Vakhrameev (1989). In the redeposited volcanogenic and terrigenous sediments, plant fossils reflecting the ancient vegetation of upland habitats were preserved. The Arman Flora from 


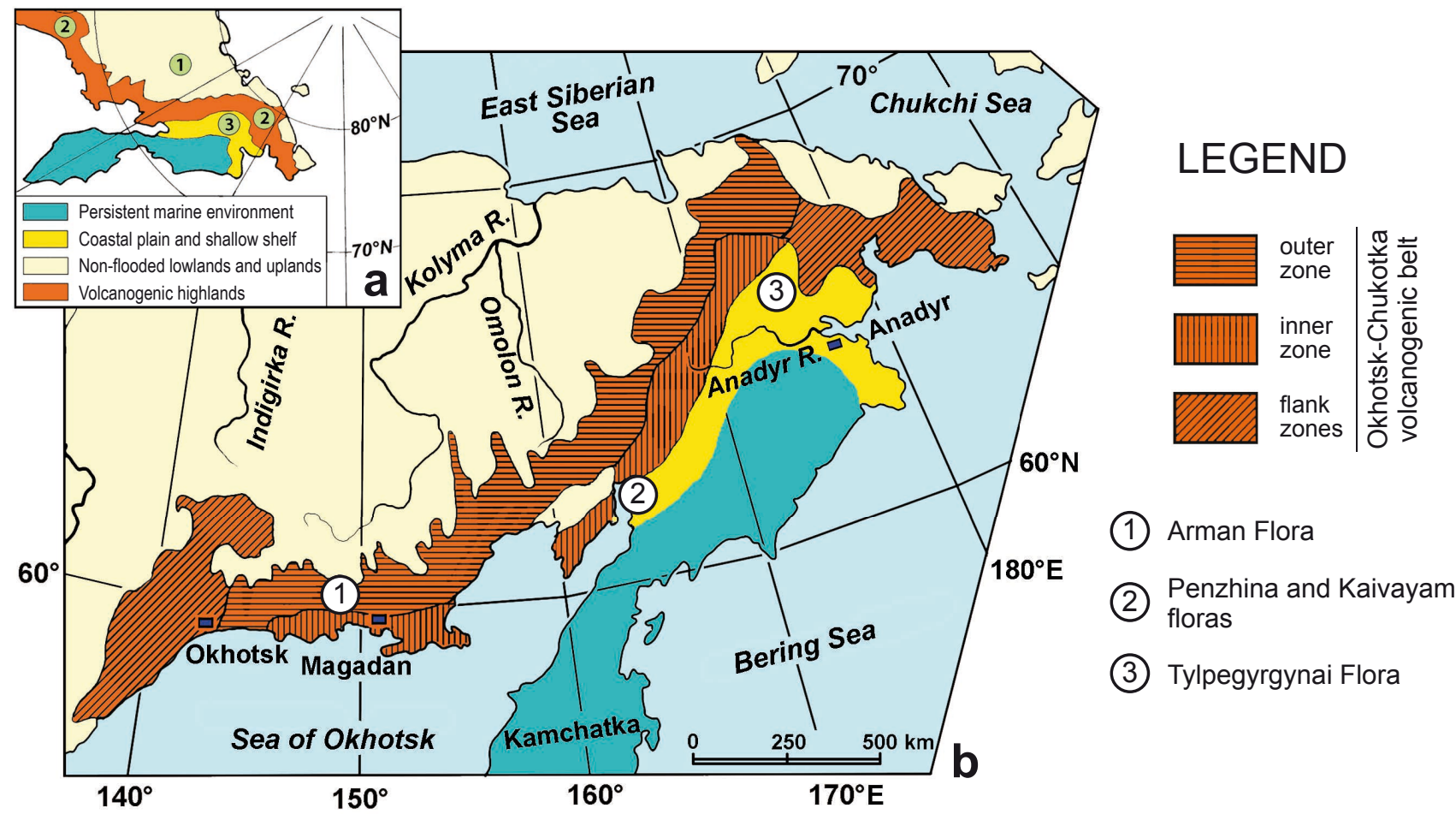

Text-fig. 2. Latest Albian - Late Cretaceous palaeobotanical-palaeogeographical subregions of the North Pacific Region (a); modern outline of North-eastern Asia is shown for the Coniacian (after Smith et al. 1981): 1 - the Verkhoyansk-Chukotka Subregion, 2 - the Okhotsk-Chukotka Subregion, 3 - the Anadyr-Koryak Subregion (modified from Herman 2013) and geographical and geological position of the Turonian - Coniacian floras (b) (present-day map, modified from Shczepetov and Herman 2013).

the volcanogenic-sedimentary deposits of the Arman Formation in the Arman River basin and NelkandyaKhasyn interfluve (Magadan District, North-eastern Russia) is one such accumulation from which 73 species of fossil plants belonging to 49 genera have been recognised and reported (Herman et al. 2016). They comprise liverworts, horsetails, ferns, seed ferns, cycadaleans, bennettitaleans, ginkgoaleans, czekanowskialeans, conifers, gymnosperms of uncertain systematic affinity and angiosperms. The Arman Flora displays a unique combination of taxa, with relatively ancient Early Cretaceous ferns and gymnosperms occurring alongside younger Late Cretaceous plants, primarily angiosperms. This flora, with its unusual combination of Early and Late Cretaceous plants, represents clear evidence of Cenophytic plant communities dominated by angiosperms entering into the Late Cretaceous volcanogenic landscape still occupied by earlier Mesophytic communities (for more details see Herman et al. 2016).

The close taxonomic similarity of the Arman Flora to the reliably dated Penzhina and Kaivayam floras of northwestern Kamchatka and the Tylpegyrgynai flora of the Pekul'nei Ridge allows the Arman Flora to be dated as
Turonian and Coniacian (Craggs 2005, Herman et al. 2016), which is corroborated by isotopic (U-Pb and ${ }^{40} \mathrm{Ar} /{ }^{39} \mathrm{Ar}$ ) age determinations for the plant-bearing layers (Akinin and Miller 2011, Herman et al. 2016).

\section{CLAMP analysis of the Arman Flora}

To derive quantitative estimates of the palaeoclimate variables experienced by the Arman Flora plants, the leaf trait spectrum for the Arman Flora was subjected to a CLAMP analysis (Climate Leaf Analysis Multivariate Program: Wolfe 1993, Yang et al. 2011; http://clamp.ibcas. ac.cn/) using the Physg3brc and gridded meteorological data set GRIDMet3br for calibration. The procedure follows the protocols given on the CLAMP website (http://clamp.ibcas. ac.cn/; see also Spicer et al. 2009, Yang et al. 2011). CLAMP correlates 31 leaf characters of woody dicots with 11 climatic parameters. This method provides estimates of several quantitative palaeoclimate variables of temperature and humidity from signals encoded in the physiognomy of fossil leaves of woody dicotyledons: mean annual temperature

Text-fig. 3. Fossil dicot angiosperms of the Arman Flora used to estimate palaeoclimatic variables: a - Araliaephyllum montanum Philippova, b - A. armanense A.Herman, c - A. subitum Philippova, d - A. cf. leonovii A.Herman, e - Araliaephyllum sp., f Diospyrophyllum latifolium A.Herman, g, h - Scheffleraephyllum venustum (Philippova) Philippova, i - Cissites bidentatus (Philippova) A.Herman, j, $\mathrm{k}$ - C. cordatus Philippova, l - Menispermites orientalis Golovn., m - M. sibiricus (Heer) Golovn., n - Terechovia philippovae A.Herman, o, p - Trochodendroides armanensis Philippova, q - Trochodendroides sp., r, s - T. minuta A.Herman, $\mathrm{t}$ - T. tumanensis Yudova, $\mathrm{u}$ - Cocculophyllum sp., $\mathrm{v}$ - Parvileguminophyllum samylinae A.Herman, w - Dalbergites sp., $\mathrm{x}$ - Arthollia pacifica A.Herman, $\mathrm{y}$ - Paraprotophyllum basicordatum A.HERMAN, z, aa - Ettingshausenia louravetlanica (A.HeRMAN et Shczepetov) A.Herman et M.Moiseeva, ab - Pseudoprotophyllum boreale (Dawson) Hollick, ac - Celastrophyllum orientale Philippova, ad, ae, af - Dalembia pergamentii A.Herman et Lebedev. Scale bar $1 \mathrm{~cm}$. 


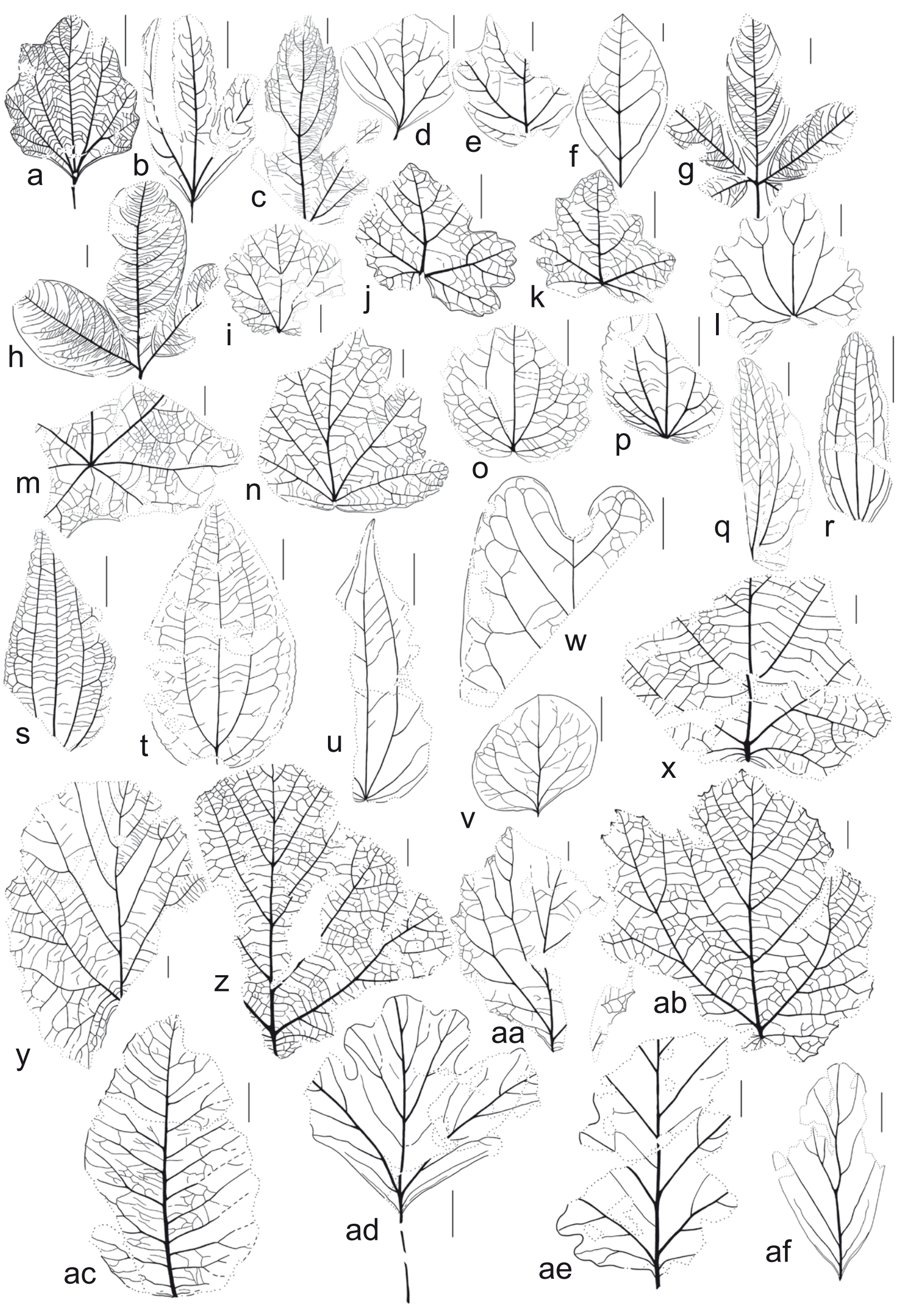

(MAT), warm month mean temperature (WMMT), cold month mean temperature (CMMT), length of the growing season (LGS), growing season precipitation (GSP), mean monthly growing season precipitation (MMGSP), precipitation during the three consecutive wettest months (3WET), precipitation during the three consecutive driest 
months (3DRY), relative humidity (RH), specific humidity (SH) and enthalpy (ENTHAL).

The Arman Flora exhibits a high diversity of fossil angiosperms (28 dicot species). In the present study 26 dicot leaf morphotypes were scored for as many of the 31 characters as were preserved. Two species were excluded from the analysis: aquatic Brasenites ochoticus A.Herman and poorly preserved Dicotylophyllum sp. The following species of the Arman Flora were scored (Text-fig. 3): Araliaephyllum armanense A.Herman, A. cf. leonovii A.Herman, A. montanum Philippova, A. subitum Philippova, Araliaephyllum sp., Myrtophyllum acuminatum (PHILIPPova) A.Herman et Shczepetov, Scheffleraephyllum venustum (Philippova) Philippova, Cissites bidentatus (Philippova) A.Herman, C. cordatus Philippova, Cocculophyllum sp., Menispermites orientalis Golovn., M. sibiricus (Heer) Golovn., Terechovia philippovae A.Herman, Diospyrophyllum latifolium A.HeRMAn, Trochodendroides armanensis Philippova, T. minuta A.Herman, T. tumanensis Yudova, Trochodendroides sp., Arthollia pacifica A.Herman, Ettingshausenia louravetlanica (A.Herman et Shczepetov) A.Herman et M.Moiseeva, Paraprotophyllum basicordatum A.Herman, Pseudoprotophyllum boreale (Dawson) Hollick, Celastrophyllum orientale Philippova, Dalembia pergamentii A.Herman et Lebedev, Dalbergites sp., Parvileguminophyllum samylinae A.Herman.

The scoring results (percentage of characters preserved) are: Leaf margin: leaves lobed - $30 \%$; leaves with no teeth $28 \%$; teeth regular $-64 \%$; teeth close $-68 \%$; teeth round $30 \%$; teeth acute $-42 \%$; teeth compound $-12 \%$.

Leaf size: nanophyll - $0 \%$; leptophyll I - $0 \%$; leptophyll II - $0 \%$; microphyll I - $8 \%$; microphyll II - $48 \%$; microphyll III - $22 \%$; mesophyll I - $13 \%$; mesophyll II $5 \%$; mesophyll III $-0 \%$.

Leaf apex: emarginate $-4 \%$; round $-12 \%$; acute $-32 \%$; attenuate $-4 \%$.

Leaf base: cordate $-33 \%$; round $-29 \%$; acute $-33 \%$.

Leaf length to width ratio: less that $1: 1(22 \%) ; 1: 1$ to $2: 1(61 \%) ; 2: 1$ to $3: 1$ (7\%); $3: 1$ to $4: 1$ (1\%); more that $4: 1(0 \%)$.

Leaf shape: obovate $-10 \%$; elliptic $-62 \%$; ovate $-20 \%$.

\section{Estimates of the temperature and humidity experienced by the Arman Flora plants}

The results of the CLAMP analyses using the gridded meteorological calibration data set GRIDMet3br and the Physg3brc set of foliar physiognomic scores are shown in Table 1. In terms of temperature and humidity, the estimated variables suggest that the Arman Flora existed in a warm temperate humid climate with warm summers, mild winters and rather small seasonal differences in precipitation. Here we use the Köppen classification of modern global climates (Köppen 1936, Peel et al. 2007) defining the warm temperate climate, or climate $\mathrm{C}$, as a rainy climate with mild winters: the coolest month above $-3{ }^{\circ} \mathrm{C}$ but below $+18{ }^{\circ} \mathrm{C}$, and the warmest month above $10^{\circ} \mathrm{C}$. However, taking into account the possible uncertainties of our estimates (Tab. 1), it is possible that the Arman Flora indicates a cold temperate climate (in its warmest form - climate D by Köppen), in which the coldest month temperature could occasionally drop below $-3{ }^{\circ} \mathrm{C}$.

Temperature and humidity variables of the palaeoclimate in which the Arman Flora existed are especially similar to, or even the same (within the errors) as those estimated from fossil dicot leaf physiognomy of the Penzhina Flora (late Turonian, north-western Kamchatka Peninsula), the Kaivayam Flora (Coniacian, north-western Kamchatka Peninsula) and the Tylpegyrgynai Flora (early Coniacian, Pekulnei Ridge) (Tab. 1), consistent with the taxonomic similarities between these floras. These three floras existed on the coastal plains and lowlands east of the volcanic belt (Text-fig. 2). This close similarity of the variables allows us to infer that the biotope of the Arman Flora probably existed at a relatively low elevation above these lowlands because elevation had no discernible effect on the temperature and humidity parameters reflected by leaf physiognomy of the Arman plants.

\section{Palaeoelevation of the Arman Flora site estimate}

CLAMP technique can be applied to estimate directly the palaeoelevation of palaeovegetation sourcing a fossil site. The difference in enthalpy at a known elevation (such as sea-level) and a land-surface at an unknown height is given by the following equation (Spicer et al. 2003, Jacques et al. 2014, Spicer 2018):

Table 1. Palaeoclimate variables estimated using the CLAMP technique applied for the Turonian - Coniacian floras of North-eastern Russia (modified from Spicer and Herman 2010).

\begin{tabular}{|c|c|c|c|c|c|c|c|c|c|}
\hline $\begin{array}{l}\text { Fossil flora } \\
\text { (its age) }\end{array}$ & $\begin{array}{l}\text { MAT } \\
\left({ }^{\circ} \mathbf{C}\right)\end{array}$ & $\begin{array}{c}\text { WMMT } \\
\left({ }^{\circ} \mathbf{C}\right)\end{array}$ & $\begin{array}{l}\text { CMMT } \\
\left({ }^{\circ} \mathrm{C}\right)\end{array}$ & $\begin{array}{c}\text { LGS } \\
\text { (months) }\end{array}$ & $\begin{array}{r}\text { GSP } \\
(\mathbf{m m})\end{array}$ & $\begin{array}{c}\text { MMGSP } \\
(\mathbf{m m})\end{array}$ & $\begin{array}{l}\text { 3WET } \\
(\mathrm{mm})\end{array}$ & $\begin{array}{l}\text { 3DRY } \\
(\mathbf{m m})\end{array}$ & $\begin{array}{c}\text { Enthalpy } \\
(\mathrm{kJ} / \mathrm{kg})\end{array}$ \\
\hline $\begin{array}{l}\text { Arman } \\
\text { (Turonian - Coniacian) }\end{array}$ & 8.2 & 18.7 & -2.0 & 5.3 & 481 & 88 & 481 & 143 & 304 \\
\hline $\begin{array}{l}\text { Penzhina } \\
\text { (late Turonian) }\end{array}$ & 7.7 & 17.7 & -2.4 & 5.1 & 427 & 82 & 466 & 144 & 304 \\
\hline $\begin{array}{l}\text { Kaivayam } \\
\text { (Coniacian) }\end{array}$ & 9.6 & 18.3 & 1.1 & 6.0 & 598 & 88 & 519 & 154 & 310 \\
\hline $\begin{array}{l}\text { Tylpegyrgynai (early Coniacian) } \\
\text { (Craggs 2005) }\end{array}$ & 8.4 & 18.8 & -1.6 & 5.4 & 476 & 82 & 493 & 126 & 303 \\
\hline Standard deviation $(2 \sigma)$ & 1.1 & 1.4 & 1.9 & 0.7 & 196 & 26 & 138 & 32 & 5 \\
\hline
\end{tabular}




$$
\mathrm{Z}=\left(\mathrm{H}_{\text {sea level }}-\mathrm{H}_{\text {altitude }}\right) / \mathrm{g},
$$

where $\mathrm{Z}$ is the height difference, $\mathrm{H}_{\text {sea level }}$ is enthalpy at sea level, $H_{\text {altitude }}$ is enthalpy at the unknown altitude, $g$ is gravitational acceleration $\left(9.81 \mathrm{~m} / \mathrm{s}^{2}\right)$.

Enthalpy at sea-level can be obtained from a coeval locality at sea-level (as evidenced, for example, by the fossil floras being associated with sediments that inter-finger with marine deposits) and at the same latitude. In this study, sea level enthalpy is estimated, using the same calibration, for the Penzhina and Kaivayam floras of north-western Kamchatka (Herman and Lebedev 1991, Herman 2011; http:// arcticfossils.nsii.org.cn/), which existed in lowlands near the seashore (Tab. 1). The maximum difference in heights obtained from the mean enthalpies is $(310-304) / 9.81=$ $0.61 \mathrm{~km}$. This value represents the most probable elevation of the Arman Flora site above that of the Kaivayam Flora and consequently of sea level. However, this estimate carries large uncertainties (S.D. $=0.8 \mathrm{~km}$ ) involved in the method itself (http://clamp.ibcas.ac.cn) as well as in geographic (palaeolatitude) and stratigraphic (age) positioning of the fossil floras analysed. However, this low elevation estimate is again consistent with the compositional similarity between the Arman and nearby coastal palaeofloras. This may indicate that the 'uplands' of the Okhotsk-Chukotka volcanogenic belt in the Late Cretaceous mainly consisted of individual volcanic peaks separated by a relatively subdued landscape, similar perhaps to that of the modern Cascade range in the northeastern United States.

\section{Acknowledgments}

I am sincerely grateful to Robert A. Spicer (the Open University, Milton Keynes, Great Britain) and Sergei V. Shczepetov (Komarov Botanical Institute, Russian Academy of Sciences, St. Petersburg, Russia), with whom I discussed the palaeoenvironment of the Arman Flora. I am also grateful to Bob Spicer and Adam Halamski (Institute of Paleobiology, Polish Academy of Sciences, Warszawa, Poland) for their helpful comments and amendments to the manuscript. The research was performed within the framework of the State program no. 0135-2016-0001 (Geological Institute, Russian Academy of Sciences).

\section{References}

Akinin, V. V., Miller, E. L. (2011): Evolution of calcareous-alkaline magmas of the Okhotsk-Chukotka volcanogenic belt. - Petrology, 19(3), 237-277.

https://doi.org/10.1134/S0869591111020020

Belyi, V. F. (1977): Stratigrafiya i struktury Okhotsko-Chukotskogo vulkanogennogo poyasa [Stratigraphy and Structures of the Okhotsk-Chukotka Volcanogenic Belt]. - Nedra, Moscow, 171 pp. (in Russian)

Craggs, H. J. (2005): Late Cretaceous climate signal of the Northern Pekulney Range flora of northeastern Russia. Palaeogeography, Palaeoclimatology, Palaeoecology, 217: 25-46.

https://doi.org/10.1016/j.palaeo.2004.11.014
Herman, A. B. (1999): Melovaya Flora Anadyrsko-Koryakskogo Subregiona (Severo-Vostok Rossii): Sistematicheskiy Sostav, Vozrast, Stratigraficheskoye i Florogeneticheskoye Znacheniye [Cretaceous Flora of the Anadyr-Koryak Subregion (Northeastern Russia): Systematics, Age, Stratigraphic and Florogenic Significance]. - GEOS, Moscow, 122 pp. (in Russian)

Herman, A. B. (2011): Al'bskaya - Paleotsenovaya Flora Severnoi Patsifiki [Albian - Paleocene Flora of the North Pacific Region]. - GEOS, Moscow, 280 pp. (in Russian)

Herman, A. B. (2013): Albian - Paleocene Flora of the North Pacific: Systematic Composition, Palaeofloristics and Phytostratigraphy. - Stratigraphy and Geological Correlation, 21(7): 689-747. https://doi.org/10.1134/S0869593813070034

Herman, A. B., Golovneva, L. B., Shchepetov, S. V., Grabovsky, A. A. (2016): The Late Cretaceous Arman Flora of Magadan Oblast, Northeastern Russia. - Stratigraphy and Geological Correlation, 24(7): 651-760. https://doi.org/10.1134/S0869593816070029

Herman, A. B., Lebedev, E. L. (1991): Stratigrafiya i Flora Melovykh Otlozhenii Severo-Zapadnoi Kamchatki [Cretaceous Stratigraphy and Flora of northwestern Kamchatka]. - Nauka, Moscow, 141 pp. (in Russian)

Jacques, M. B. F., Su, T., Spicer, R. A., Xing, Y.-W., Huang, Y.-J., Zhou, Z.-K. (2014): Late Miocene southwestern Chinese floristic diversity shaped by the southeastern uplift of the Tibetan Plateau. - Palaeogeography, Palaeoclimatology, Palaeoecology, 411: 208-215. https://doi.org/10.1016/j.palaeo.2014.05.041

Köppen, W. (1936): Das geographische System der Klimate. - In: Köppen, W., Geiger, R. (eds), Handbuch der Klimatologie. Gebrüder Bornträger, Berlin, pp. 1-44.

Peel, M. C., Finlayson, B. L., McMahon, T. A. (2007): Updated world map of the Köppen-Geiger climate classification. - Hydrology and Earth System Sciences, 11: $1633-1644$. https://doi.org/10.5194/hess-11-1633-2007

Shczepetov, S. V., Herman, A. B. (2013): Kholokhovchanskiy floristicheskiy kompleks pozdnego mela Okhotsko-Chukotskogo vulkanogennogo poyasa (Severo-Vostok Azii) [Late Cretaceous Kholokhovchan floral assemblage of the Okhotsk-Chukotka volcanogenic belt (North-eastern Asia)]. - In: Golovneva, L. B. (ed.), Paleobotanika, Vol. 4. Marafon Publ., St. Petersbourg, pp. 116-147 (in Russian)

Smith, A. G., Hurley, A. M., Briden, J. C. (1981): Phanerozoic paleocontinental world maps. - Cambridge University Press, Cambridge, London, New York, New Rochelle, Melbourn, Sydney, 102 pp.

Spicer, R. A. (2018): Phytopaleoaltimetry: using plant fossils to measure past land surface elevation. - In: Hoorn, C., Perrigo, A., Antonelli, A. (eds), Mountains, Climate and Biodiversity. Willey-Blackwell, Oxford, pp. 95-109.

Spicer, R. A., Ahlberg, A., Herman, A. B., Hofmann, C.C., Raikevich, M., Valdes, P. J., Markwick, P. J. (2008). The Late Cretaceous continental interior of Siberia: A challenge for climate models. - Earth and Planetary Science Letters, 267: 228-235. https://doi.org/10.1016/j.eps1.2007.11.049

Spicer, R. A., Harris, N. B. W., Widdowson, M., Herman, A. B., Guo, Sh., Valdes, P. J., Wolfe, J. A., Kelley, S. P. 
(2003): Constant elevation of southern Tibet over the past 15 million years. - Nature, 421: 622-624.

https://doi.org/10.1038/nature01356

Spicer, R. A., Herman, A. B. (2010): The Late Cretaceous environment of the Arctic: a quantitative reassessment based on plant fossils. - Palaeogeography, Palaeoclimatology, Palaeoecology, 295: 423-442. https://doi.org/10.1016/j.palaeo.2010.02.025

Spicer, R. A., Valdes, P. J., Spicer, T. E. V., Craggs, H. J., Srivastava, G., Mehrotra, R. C., Yang, J. (2009): New developments in CLAMP: calibration using global gridded meteorological data. - Palaeogeography, Palaeoclimatology, Palaeoecology, 283(1-2): 91-98. https://doi.org/10.1016/j.palaeo.2009.09.009

Vakhrameev, V. A. (1989): Migratsii drevnikh golosemennykh v yurskoye i melovoye vremya i prichiny etogo yavleniya [Migration of ancient gymnosperms in Ju- rassic and Cretaceous and reasons for this]. - In: Voprosy paleofloristiki i stratigrafii [Topics on Palaeofloristics and Stratigraphy]. Leningrad, Nauka, pp. 31-40. (in Russian)

Vakhrameev, V. A. (1991): Jurassic and Cretaceous Floras and Climates of the Earth. - Cambridge University Press, Cambridge, $318 \mathrm{pp}$.

Wolfe, J. A. (1993): A method of obtaining climatic parameters from leaf assemblages. - U. S. Geological Survey Bulletin, 2040: 1-73. https://doi.org/10.3133/b2040

Yang, J., Spicer, R. A., Spicer, T. E. V., Li, C. S. (2011): 'CLAMP Online': a new web-based palaeoclimate tool and its application to the terrestrial Paleogene and Neogene of North America. - Palaeobiodiversity and Palaeoenvironments, 91: 163-183.

https://doi.org/10.1007/s12549-011-0056-2 